\section{Therapeutic anti-CD3 monoclonal antibodies: from bench to bedside}

The induction of tolerance is a major goal of immunotherapy. Investigations over the last 20 years have shown that anti-CD3 monoclonal antibodies (mAbs) effectively treat autoimmune disease in animal models and have also shown promise in clinical trials. Tolerance induction by anti-CD3 mAbs is related to the induction of Tregs that control pathogenic autoimmune responses. Here, we review preclinical and clinical studies in which intravenous or mucosal administration of anti-CD3 mAbs has been employed and provide an outlook on future developments to enhance the efficacy of this promising therapeutic approach.

First draft submitted: 4 April 2016; Accepted for publication: 27 April 2016; Published online: 10 May 2016

Keywords: autoimmune diseases $\bullet$ foralumab $\bullet$ immune tolerance $\bullet$ immunotherapy - monoclonal CD3 antibodies $\bullet$ otelixizumab • Tregs • teplizumab • Type 1

diabetes $\bullet$ visilizumab

\section{Background}

The success story of monoclonal antibodies ( $\mathrm{mAbs}$ ) began with the discovery of hybridoma technology for production of murine mAbs, in the 1970s by G. Köhler and C. Milstein, who were awarded by the Nobel Prize in Physiology or Medicine in 1984. Kung et al. reported in 1979 the development of OKT3 (Ortho Kung T3), the first $\mathrm{mAb}$ recognizing $\mathrm{CD} 3$ surface antigen on human T cells [1]. Marketed under the name muromonab, OKT3 was the first monoclonal murine antibody to become available for therapy in humans. In 1986 OKT3 was approved by the US FDA for inhibiting rejection in solid-organ transplantation. This mouse IgG2a is directed against the CD3 epsilon chain of the CD3/TCR complex that characterizes $\mathrm{T}$ lymphocytes and has been successfully used to treat allograft rejection in kidney, liver and heart transplantation [2] . A clinical trial with patients suffering from multiple sclerosis (MS) also showed potential of this anti-CD3 $\mathrm{mAb}$ to inhibit relapse of disease [3]. However, further clinical development of this antibody was halted due to its side effects. Being a $\mathrm{mAb}$ of murine origin, OKT3 is extremely immunogenic in humans, eliciting a high titer of antimouse antibodies in most patients $[4,5]$. Moreover, OKT3 is a potent mitogen, promoting T-cell proliferation and cytokine secretion, triggering a wide spectrum of side effects that include fever, chills nausea, vomiting and headaches, summarized as 'flu-like,' 'cytokine-release' or 'first-dose' syndrome. A small portion of patients suffers even more severe side effects such as cardiopulmonary distress, seizures, encephalopathy, meningitis, renal insufficiency and graft thrombosis [6].

Anti-CD3 mAb were 'rediscovered' thanks to the development of a mouse specific anti-CD3 $\mathrm{mAb}$ (clone 145-2C11) in the late $80 \mathrm{~s}$ [7] that allowed exploring the side effects as well as the mechanisms underlying immunotherapy with anti-CD3 $\mathrm{mAb}$ in mouse models. This led to the seminal finding by Chatenoud et al. in the 90s
Chantal Kuhn ${ }^{1}$ \& Howard L Weiner ${ }^{*, 1}$ ${ }^{1}$ Ann Romney Center for Neurologic Diseases, Brigham \& Women's Hospital, Harvard Medical School, Boston, MA 02115, USA

*Author for correspondence: hweiner@rics.bwh.harvard.edu 
demonstrating that administration of anti-CD3 $\mathrm{mAb}$ to overt diabetic NOD (non obese diabetic, developing spontaneous autoimmune diabetes) mice induced long-lasting remission from disease [8]. This discovery initiated further successful studies on anti-CD3 $\mathrm{mAb}$ for tolerance induction in autoimmune diseases and other immune mediated pathologies [9]. The advances in genetic engineering in antibody structure permitted addressing the shortcomings of OKT3, that is, its immunogenicity and side effects. As the immunogenicity of OKT3 and its peers were caused by their rodent origin, anti-CD3 $\mathrm{mAb}$ were humanized by grafting the complementarity determining region that is key to recognizing antigen, into a human $\operatorname{IgG}$ backbone and today some antibody clones are of completely human origin [10]. Moreover, it was shown that the side effects provoked by the first generation of anti-CD3 $\mathrm{mAb}$ were caused by concomitant binding to the Fc receptors $(\mathrm{FcR})$ on antigen presenting cells and to the CD3/TCR complex on T cells, leading to strong T-cell activation and a high transient release of proinflammatory cytokines (i.e., TNF- $\alpha$, IL- 6 , IFN- $\gamma$, IL-2) by the targeted $\mathrm{T}$ cells briefly after the first administration [11,12]. After it had been shown that non-FcR binding anti-CD3 $\mathrm{mAb}$ were still tolerogenic [13], human anti-CD3 $\mathrm{mAb}$ were rendered non mitogenic by introducing mutations into the $\operatorname{IgG}$ backbone that led to highly decreased affinity to Fc receptors [14,15]. These advances led to the further development of anti-CD3 $\mathrm{mAb}$ for treatment of autoimmune diseases [16]. In this review, we will discuss the therapeutic potential of anti-CD3 $\mathrm{mAb}$ in animal models and human disease with a focus on autoimmune diseases, the mechanisms underlying tolerance induction by anti-CD3 $\mathrm{mAb}$, current clinical developments in this field as well as challenges and future directions.

\section{Tregs in autoimmune diseases}

Autoimmune diseases are triggered by autoreactive $\mathrm{T}$ and $\mathrm{B}$ cells that escape mechanisms of immune tolerance. Tregs are essential gatekeepers of immune tolerance by suppressing activation, proliferation and effector responses of both innate and adaptive immune cells. Treg are a heterogeneous population with respect to their origin of development, phenotype, functional activity and activation status and are generally categorized into natural/thymus derived Treg (tTreg) cells and induced/peripherally derived Treg (pTreg) [17], recently joined by a group of tissue resident Tregs [18]. Natural Treg are selected in the thymus thanks to their relatively high-affinity interaction with self-peptide/ MHC class II complexes $[19,20]$ and comprise $5-10 \%$ of the peripheral $\mathrm{CD}^{+} \mathrm{T}$ cells in mice and humans. They are characterized by expression of the IL-2R $\alpha$-chain
(CD25) [21] and the transcription factor FoxP3 that is essential for their regulatory function and for control of autoimmunity [22,23]. Peripheral Treg are induced by foreign antigen under tolerogenic conditions and thus are an attractive target for antigen-specific immunotherapy. Peripherally induced Treg mostly refer to TGF- $\beta$ induced FoxP3 ${ }^{+}$Treg [24], IL-10 secreting Tr1 cells [25], Th3 cells that express membrane bound TGF- $\beta$ being held in a latent state by LAP $[26,27]$, but also include inducible $\mathrm{CD} 8{ }^{+}$Treg, $\mathrm{CD}^{+}{ }^{+} \mathrm{CD} 4{ }^{-} \mathrm{CD} 8-$ Treg, $\mathrm{CD}^{+}{ }^{+} \mathrm{V} \alpha 14^{+} \mathrm{NKTreg}$ and $\gamma \delta$ Treg [28]. Tregs control autoimmunity by secretion of inhibitory cytokines (e.g., IL-10 [29], TGF- $\beta$ [30] and IL-35 [31]), granzyme/ perforin induced apoptosis of effector lymphocytes [32], depriving effector $T$ cells of cytokines leading to apoptosis, inhibition of dendritic cell function [33,34] or metabolic disruption [35]. Most if not all autoimmune diseases have been associated with alterations of Tregs in terms of frequency and/or function, making these cells appealing therapeutic targets for immunotherapy of autoimmune diseases [36]. Of note, anti-CD3 mAb therapy is associated with an increase of the number and function of several subpopulations of Treg and of the regulatory cytokines TGF- $\beta$ and IL-10. These parameters might be useful biomarkers for indicating treatment success in patients.

\section{Anti-CD3 mAb in animal models}

\section{Intravenous administration of anti-CD3 mAb}

Much of what we know about the mode of action, the pharmacodynamics and the tolerogenic activity of anti-CD3 $\mathrm{mAb}$ in autoimmune diseases derives from animal models. As anti-CD3 $\mathrm{mAb}$ are strictly species specific, meaning that human anti-CD3 $\mathrm{mAb}$ do not crossreact with $T$ cells from mice, it wasn't until the development of the anti-mouse anti-CD3 $\mathrm{mAb}$ $145-2 \mathrm{C} 11$ [7] that the therapeutic potential of anti$\mathrm{CD} 3 \mathrm{mAb}$ and the underlying mechanisms could be explored in mouse models. Until 1994 only the immunosuppressive properties of anti-CD3 $\mathrm{mAb}$ through depletion of $\mathrm{T}$ cells were known. Chatenoud et al. were the first to demonstrate the tolerogenic properties of intravenously administered anti-CD3 $\mathrm{mAb}[8]$. A 5-day treatment of overt diabetic NOD mice with the anti-CD3 $\mathrm{mAb} 145-2 \mathrm{C} 11$ [8] or $\mathrm{F}\left(\mathrm{ab}^{\prime}\right)$ fragments of 145-2C11 [13] induced rapid, long-lasting and antigen-specific remission from disease and also prevented immune response toward syngeneic pancreatic islet grafts but not against unrelated antigens as shown by normal rejection of skin allografts [8]. Since then intravenous administration of anti-CD3 $\mathrm{mAb}$ has been successfully tested in numerous animal models of autoimmunity [16], including the EAE (experimental autoimmune encephalomyelitis) model of MS [37,38], 
TNP-KLH induced colitis (a model of inflammatory bowel disease [IBD]) [39] and collagen-induced arthritis (modeling rheumatoid arthritis) [40]. In addition to autoimmunity, anti-CD3 $\mathrm{mAb}$ also improved the outcome of graft versus host disease [41,42], transplantation [43-46] and atherosclerosis [47]. The observation that anti-CD3 $\mathrm{mAb}$ are able to halt active autoimmunity but less efficient in preventing disease $[13,38]$ led to an important discovery in the field of transplantation. While administration at the time of transplantation induces immunosuppression, a slightly delayed treatment can induce long-lasting remission in pancreatic islet grafts [45] and heart transplantation [46], probably due to preferential depletion of activated effector $\mathrm{T}$ cells, resistance of Tregs to anti-CD3 mAb-induced apoptosis and establishment of local immune privilege, factors discussed in more detail in the following paragraph.

\section{How does intravenous administration of anti- $\mathrm{CD} 3 \mathrm{mAb}$ induce tolerance in autoimmune diseases?}

Therapeutic anti-CD3 $\mathrm{mAb}$ bind to the epsilon chain of the CD3/TCR complex that characterizes T lymphocytes [48-50]. Much of what we know about anti$\mathrm{CD} 3 \mathrm{mAb}$ and their therapeutic potential derives from research on NOD mice that spontaneously develop autoimmune diabetes [16,51]. Several nonmutually exclusive mechanisms have been proposed to explain the therapeutic effect of intravenously administered anti-CD3 $\mathrm{mAb}$ (see Figure 1). After a short lasting capping of the CD3 complex, the CD3/T-cell receptor complex disappears from the cell surface by internalization or shedding, a process called antigenic modulation that renders $\mathrm{T}$ cells temporarily blind to their cognate antigens [52]. Anti-CD3 mAb-induced signaling preferentially induces anergy [53] or apoptosis in activated $\mathrm{T}$ cells while sparing Tregs [51,54]. Heterogeneity of TCR expression by different T-cell subsets might explain the differential effect of anti-CD3 $\mathrm{mAb}$ on effector versus regulatory or naïve T cells [55]. The tolerogenic function of anti-CD3 $\mathrm{mAb}$ is independent of effector functions that are linked to the Fc region of the antibody, such as complement-dependent cytotoxicity (CDC), antibody-dependent cellular cytotoxicity (ADCC) and antibody-dependent cell phagocytosis (ADCP), as $\mathrm{F}\left(\mathrm{ab}^{\prime}\right)_{2}$, fragments are sufficient for tolerance induction [13]. It has been shown that $T$ cells become rapidly activated in response to intravenous anti-CD3 $\mathrm{mAb}$ as measured by increased expression of CD69 and CD25 and serum concentrations of TGF- $\beta$ and IFN- $\gamma$ briefly after injection, even when using nonmitogenic anti-CD3 $\mathrm{mAb}[56,57]$. The direct effects of anti-CD3 mAb on T cells (capping, antigenic modulation, induction of apoptosis and anergy) are all short-term and are gone after clearance of the antibody from the circulation. Yet, the pharmacological effects mediated by anti-CD3 mAb therapy are long lasting, indicating that additional and more durable mechanisms are involved in anti-CD3 $\mathrm{mAb}$ mediated tolerance. Perruche et al. showed a link between antiCD3 mAb-induced apoptosis, phagocytosis of the resulting apoptotic bodies by macrophages and a subsequent increase of TGF- $\beta$ [58]. TGF- $\beta$ plays an essential role in regulating immune responses and the production of TGF- $\beta$ is crucial for the therapeutic effect of anti-CD3 mAb [59]. TGF- $\beta$ has pleiotropic effects on the adaptive immunity [60], including induction of adaptive FoxP3 ${ }^{+}$Tregs [61], inhibition of T-cell activation and proliferation [62] and blocking dendritic cell maturation [63], and all these outcomes are observed after anti-CD3 $\mathrm{mAb}$ mediated tolerance induction. Indeed, it has been demonstrated that anti-CD3 $\mathrm{mAb}$ therapy increases TGF- $\beta$ dependent Tregs [59], renders effector T cells more susceptible to TGF- $\beta$ mediated regulation [64] and confers a tolerogenic phenotype to dendritic cells [51]. Several groups found that anti-CD3 $\mathrm{mAb}$ have a distinct effect on intestinal $\mathrm{T}$ cells $[65,66]$. Anti-CD3 mAb were shown to trigger accumulation of regulatory Th17 cells expressing IL-10 in the small intestine via CCR6/CCL20 dependent migration [65]. Similarly, administration of human anti-CD3 $\mathrm{mAb}$ to humanized mice (immunodeficient mice reconstituted with human hematopoietic stem cells) induced gut tropic regulatory $\mathrm{CD} 4^{+} \mathrm{CD} 25^{\text {high }} \mathrm{CCR} 6{ }^{+} \mathrm{FoxP}_{3}{ }^{+}$ $T$ cells that secreted IL-10 [66]. Blocking migration of cells to the gut with anti-integrin $\alpha 4 \mathrm{mAb}$ abrogated the therapeutic effect. $\mathrm{CD} 4{ }^{+} \mathrm{CD} 25^{\text {high }} \mathrm{CCR} 6{ }^{+} \mathrm{FoxP}^{+}{ }^{+}$ $\mathrm{T}$ cells were also increased in patients with Type 1 diabetes (T1D) that received anti-CD3 mAb [66]. Stimulation of intestinal tissue samples from patients with cancer or IBD or healthy controls with anti-CD3 $\mathrm{mAb}$ led to a decrease of proinflammatory cytokines and chemokines and an increase of IL-10. Blocking IL-10 abrogated the anti-inflammatory effect of anti$\mathrm{CD} 3 \mathrm{mAb}$ [67]. Of note, IL-10 induction by anti-CD3 $\mathrm{mAb}$ was observed in all these studies investigating the effect of anti-CD3 $\mathrm{mAb}$ on intestinal T cells and IL-10 is a key anti-inflammatory cytokine regulating intestinal homeostasis and controlling IBD [68]. Anti$\mathrm{CD} 3 \mathrm{mAb}$ are currently being tested in clinical trials for IBD (see chapter on clinical development of anti$\mathrm{CD} 3 \mathrm{mAb}$ ). In vitro anti-CD3 $\mathrm{mAb}$ stimulation of lamina propria derived $\mathrm{CD}^{+} \mathrm{T}$ cells, but not $\mathrm{CD}^{+}$ $\mathrm{T}$ cells or $\mathrm{T}$ cells from peripheral blood, from healthy controls or patients with IBD led to apoptosis (dependent on caspase 3 and caspase 8) [69]. Anti-CD3 mAb therapy has also been associated with the TNF depen- 


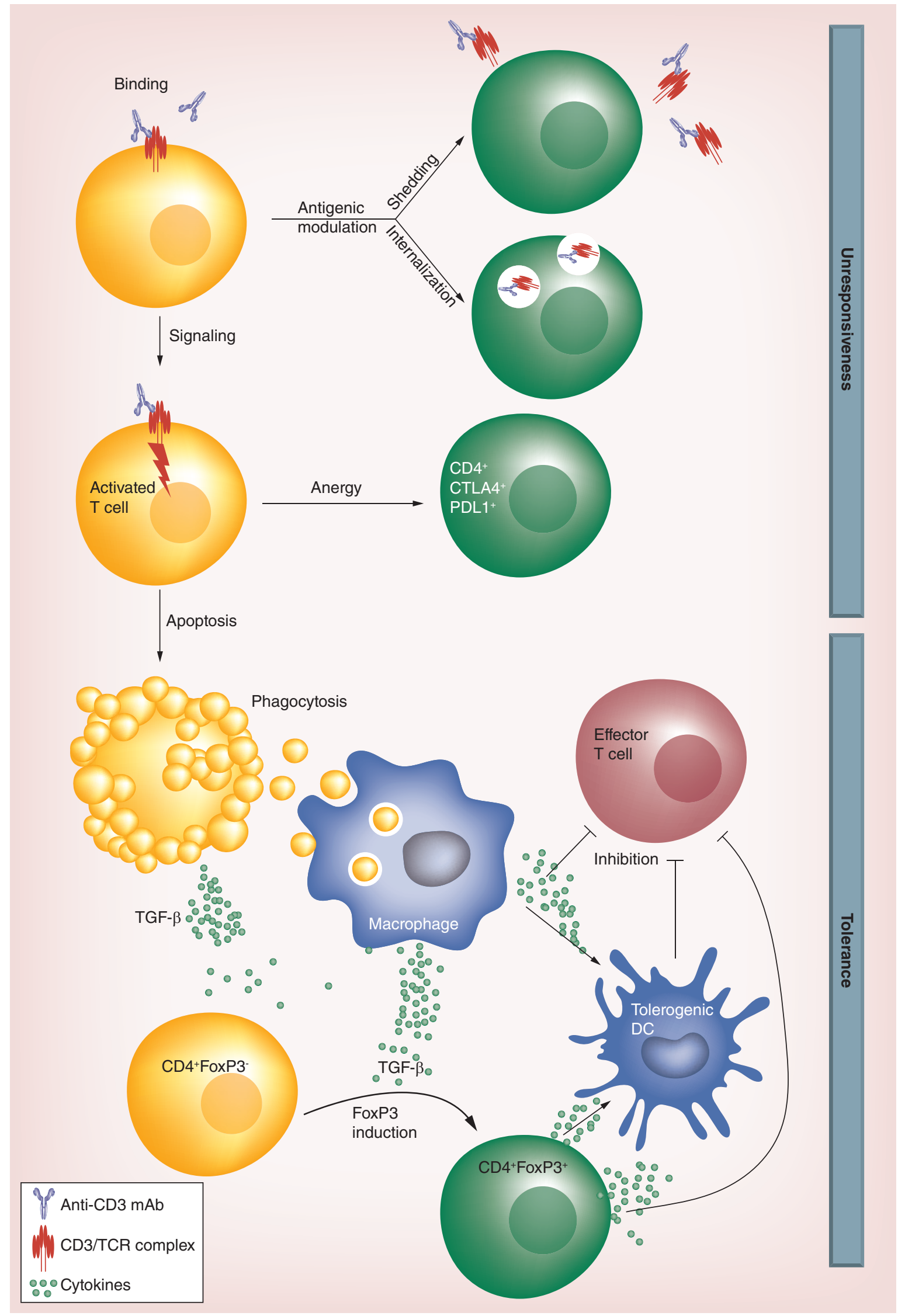


Figure 1. Tolerance induction by intravenously administered anti-CD3 mAb is a multistep process (see facing page). Binding of anti-CD3 mAb to the CD3/TCR complex leads to antigenic modulation, i.e., disappearance of the CD3/TCR from the cells surface by shedding or internalization, rendering $T$ cells blind toward their cognate antigen. At the same time anti-CD3 mAb-induced signaling through the CD3/TCR complex can render the T cell anergic or trigger apoptosis. While antigenic modulation and anergy only render lymphocytes ignorant to antigen and lead to transient immunosuppression, anti-CD3 mAb-induced tolerance is dependent on apoptosis. Apoptotic T cells and macrophages that ingest the apoptotic bodies both produce TGF- $\beta$ that promotes a tolerogenic microenvironment. TGF- $\beta$ can induce FoxP3 in CD4+ $4^{+}$cells, rendering them suppressive. Both, TGF- $\beta$ and $\mathrm{CD}^{+}{ }^{+} \mathrm{FoxP}^{+} \mathrm{T}$ cells inhibit effector $\mathrm{T}$ cells and skew antigen presenting cells such as dendritic cells toward a tolerogenic phenotype.

dent induction of CD8 ${ }^{+}$Tregs (TNFR2 ${ }^{+} \mathrm{CD} 25^{+} \mathrm{GIT}$ $\left.\mathrm{R}^{+} \mathrm{CTLA4}{ }^{+} \mathrm{FoxP}^{+}\right)$[70]. Of note, even though anti$\mathrm{CD} 3 \mathrm{mAb}$ are not intrinsically antigen specific, the preferential induction of apoptosis in activated effector $\mathrm{T}$ cells does confer a certain degree of antigen specificity.

\section{New mouse models for testing human specific anti-CD3 $\mathrm{mAb}$}

Anti-CD3 $\mathrm{mAb}$ are strictly species specific, meaning that human specific anti-CD3 $\mathrm{mAb}$ do not cross-react with mouse CD3. Thus, it had been impossible for a long time to test human anti-CD3 $\mathrm{mAb}$ that had been developed for use in the clinics in small animal models. Two approaches addressed this issue. The laboratory of Lucienne Chatenoud developed transgenic NOD mice expressing the human CD3 epsilon chain [57]. These mice develop spontaneous autoimmune diabetes as do conventional NOD mice and enter remission from diabetes after treatment with either mouse or human specific anti-CD3 mAb. Another approach was used by Kevan Herold's laboratory, reconstituting $\mathrm{NOD} / \mathrm{SCID}$ IL $2 \gamma \mathrm{c}^{-1-}$ (NSG) mice with human hematopoetic stem cells [66]. Both models present different advantages that will help us to better understand the mechanisms underlying tolerance induction by anti-CD3 $\mathrm{mAb}$. In NOD mice expressing the human CD3 epsilon chain, the tolerogenic effect of human anti-CD3 $\mathrm{mAb}$ can be tested in the context of autoimmunity, while humanized NSG mice allow the study of how human anti-CD3 mAb impact human T cells in vivo. In vivo studies confirmed mechanistic studies that had been performed with mouse anti-CD3 $\mathrm{mAb}$ and allowed analyzing the effect of human anti-CD3 $\mathrm{mAb}$ on cytokine production, induction of Tregs and impact on effector T cells [57,66].

\section{Oral administration of anti-CD3 mAb in mice}

The gastrointestinal immune system (GALT) has the unique capacity to discriminate between potentially dangerous and harmless material, for example, raising a protective immune response against pathogenic microbes and toxins while inducing tolerance to food antigens and commensal microbes. The observations that administration of antigen via the oral route can induce changes in the immune system leading to systemic tolerance (a concept known as oral tolerance) gave rise to the hypothesis that oral anti-CD3 $\mathrm{mAb}$ could be an alternative way for tolerance induction while decreasing side effects linked to parenteral administration. While the tolerogenic effects of intravenously administered anti-CD3 $\mathrm{mAb}$ have been thoroughly investigated since the $90 \mathrm{~s}$, the discovery that oral administration of anti-CD3 $\mathrm{mAb}$ can induce tolerance is fairly recent, dating back to 2006 [71]. Oral anti-CD3 $\mathrm{mAb}$ has been demonstrated to protect from EAE and had beneficial effect when given at peak of disease by inducing dominant immune tolerance that could be transferred by $\mathrm{CD}^{+} \mathrm{T}$ cells containing a subset expressing membrane bound TGF- $\beta$ [71]. A dose-response experiment showed that a lower dose of anti-CD3 $\mathrm{mAb}(5 \mu \mathrm{g})$ was superior to higher amounts $(50$ or $500 \mu \mathrm{g})$ in inducing tolerance [71]. This may be related to the fact that peripheral Tregs are best induced by weaker, suboptimal TCR stimulation [72,73]. Similar to intravenous administration, the Fc portion was not required for the therapeutic effect [71,74]. Oral anti-CD3 $\mathrm{mAb}$ has demonstrated therapeutic efficacy in other autoimmune models such as diabetes induced by low-dose streptozocin [75], mouse models of SLE (systemic lupus erythematosus [76], CIA (collagen induced arthritis) [77] and in the $\mathrm{CD}^{+}{ }^{+} \mathrm{CD} 45 \mathrm{RB}^{\text {high }} \mathrm{T}$-cell transfer model of IBD [78]. Oral administration of anti-CD3 $\mathrm{mAb}$ has also shown promise in treatment of inflammatory conditions other than autoimmune disorders. Oral anti-CD3 mAb decreased adipose tissue inflammation and alleviated insulin resistance in ob/ob mice, an animal model of Type 2 diabetes [79]. Additionally, ApoE deficient mice that are prone to atherosclerosis had less lesions, macrophage and $\mathrm{CD}^{+}$ T-cell accumulation when treated with oral anti-CD3 $\mathrm{mAb}[80]$.

\section{How does oral anti-CD3 mAb induce tolerance?}

Similar to orally administered peptides $[81,82]$ and cytokines [83], oral anti-CD3 $\mathrm{mAb}$ retains biological activity in the gut [75]. Anti-CD3 mAb was detected in the 
villous epithelium within 30 min after administration [71] and was taken up by the gut epithelium [26]. FcR binding anti-CD3 mAb was found bound to gut dendritic cells [26]. In contrast to intravenous delivery of anti-CD3 $\mathrm{mAb}$, neither modulation of CD3/TCR complex, depletion nor proliferation of $\mathrm{T}$ cells was observed after oral administration [84]. This is most likely the reason why oral administration of anti-CD3 $\mathrm{mAb}$ does not trigger side effects, such as the systemic cytokine release that results from parenteral administration. Similarly to oral administration of low-dose antigen (oral tolerance), oral anti-CD3 $\mathrm{mAb}$ induces tolerance via induction of Tregs (Figure 2), in particular of $\mathrm{LAP}^{+} \mathrm{Th} 3$ cells $[26,85]$. LAP is a surrogate marker of latent membrane bound TGF- $\beta$. TGF- $\beta$ is secreted as a latent form associated with LAP that protects TGF- $\beta$ from activation and tethers it to the cell membrane when the adapter protein GARP is coexpressed by the same cells. The LAP/TGF- $\beta$ complex can be found on activated $\mathrm{CD}^{+}{ }^{+} \mathrm{FoxP}^{+} \mathrm{T}$ cells $[86,87]$ and $\mathrm{CD}^{+}{ }^{+}$FoxP3 $-\mathrm{T}$ cells $[87]$. $\mathrm{CD}^{+}{ }^{+} \mathrm{LAP}^{+} \mathrm{T}$ cells contribute to infectious tolerance by providing TGF- $\beta$ that can be activated by acidification, proteases, plasmin, matrix metalloproteases, thrombospondin-1 and certain $\alpha$ integrins [27]. Once active, TGF- $\beta$ can induce FoxP3 expression in $\mathrm{CD}^{+}{ }^{+} \mathrm{FoxP}^{+}{ }^{+} \mathrm{T}$ cells and inhibit T-cell proliferation, Th1 differentiation and maturation of dendritic cells [27]. It has been shown that suboptimal activation of $\mathrm{CD}^{+} \mathrm{T}$ cells triggers TGF- $\beta$-secretion and favors conversion to Foxp $3^{+}$ Tregs [88], consistent with the finding that low dose oral anti-CD3 $\mathrm{mAb}$ induces TGF- $\beta$ dependent tolerance $[71,75,80,89]$. Gavage with anti-CD3 $\mathrm{mAb}$ increased the expression of latent membrane bound TGF- $\beta$ on $\mathrm{CD}^{+}{ }^{+} \mathrm{T}$ cells. These $\mathrm{CD} 4^{+} \mathrm{CD} 25-\mathrm{LAP}^{+}$ (but not $\left.\mathrm{CD}^{+}{ }^{+} \mathrm{CD} 25^{+} \mathrm{LAP}^{-}\right) \mathrm{T}$ cells from treated mice transferred tolerance [71,75,79] and exhibited increased suppressive activity in vitro that was dependent on TGF- $\beta$ but independent on IL-10 in most studies $[71,75,80,89]$. Notably $\mathrm{CD}^{+} \mathrm{LAP}^{+} \mathrm{T}$ cells controlled expansion of $\mathrm{IL}^{1} 7^{+}$follicular T helper cells [89], Th1 responses [75,80], Th2 responses [80] and most likely Th17 responses [71] depending on the disease model. While oral anti-CD3 $\mathrm{mAb}$ appears to work in a TGF- $\beta$ dependent manner in most experimental models $[71,75,80,89]$, the therapeutic effect in the CD45RB ${ }^{\text {high }}$ induced colitis model was associated with an increase of IL-10 and TGF- $\beta$ but dependent on IL-10 [78], in line with the observation that IL-10 is of major importance in maintaining intestinal homeostasis. In conclusion, oral anti-CD3 $\mathrm{mAb}$ appears to be a very safe way of tolerance induction through generation of regulatory $\mathrm{LAP}^{+}$and $\mathrm{FoxP}^{+}$ T cells that secrete TGF- $\beta$ and IL-10.

\section{Nasal administration of anti-CD3 mAb}

Maintenance of immune homeostasis is particularly challenging at sites of constant antigen encounter not only in the GI tract but also in the respiratory tract, which led us to test if anti-CD3 $\mathrm{mAb}$ could also induce tolerance when administered nasally. Nasal anti-CD3 mAb improved symptoms of lupus in two strains of lupus prone mice in a TGF- $\beta$ and IL-10 dependent manner [76]. This was associated with an increase of IL-10 secreting $\mathrm{CD} 4{ }^{+} \mathrm{CD} 25 \mathrm{LAP}^{+}$ Tregs and a decrease of IL-17 and IL-21 producing $\mathrm{CD} 4^{+} \mathrm{ICOS}^{+} \mathrm{CXCR}^{+}$follicular $\mathrm{T}$ helper cells [76]. In collagen induced arthritis [77] nasal anti-CD3 $\mathrm{mAb}$ was superior to orally administered CD3 in preventing disease. Nasal tolerance induction depended on generation of IL-10 secreting $\mathrm{LAP}^{+} \mathrm{T}$ cells [77]. The in vivo induction of IL-10 secreting Tregs (Tr1) by nasal anti-CD3 mAb was dependent on IL-27 secreting dendritic cells in the upper airways and was controlled by the transcription factors AHR and c-maf [90]. Autocrine IL-21 was found to expand and maintain the induced $\operatorname{Tr} 1$ cells [90]. It is interesting to note that nasal tolerance induction by anti-CD3 $\mathrm{mAb}$ depends mostly on IL-10 [76] while oral tolerance induction by anti-CD3 $\mathrm{mAb}$ seems to be TGF- $\beta$ dependent $[71,75,80,89]$ (with the exception of tolerance induction in IBD that depends on IL-10) [78]. This might be due to the organ specific microenvironment favoring TGF- $\beta$ induction in the gastrointestinal immune system while leaning toward IL-10 in the respiratory tract. Nasal administration of anti-CD3 $\mathrm{mAb}$ has not yet been explored as extensively as oral administration but equally seems to be a very safe and promising therapeutic approach.

\section{Clinical development of antihuman anti-CD3 mAbs}

The current generation of anti-CD3 $\mathrm{mAb}$ that is being developed for clinical application displays very low affinity binding to $F_{c}$ receptors thanks to amino acid substitutions in the Fc portion that reduced glycosylation. Immunogenicity is negligible due to removal of rodent portions of the antibody by humanization or by the use of fully human antibodies. So far four anti-human CD3 $\mathrm{mAb}$ are in clinical development (see Figure 3). Teplizumab, also known under the names hOKT3r1 (Ala-Ala) and MGA031, is a humanized IgG1 antibody that was developed by grafting the complementarity determining region of OKT3 into a human IgG1 backbone. Introduction of two point mutations in its Fc portion decreases binding to FcR [15]. This antibody has been clinically developed by MacroGenics and Eli Lilly. Otelixizumab (ChAglyCD3, TRX4, GSK2136525) 


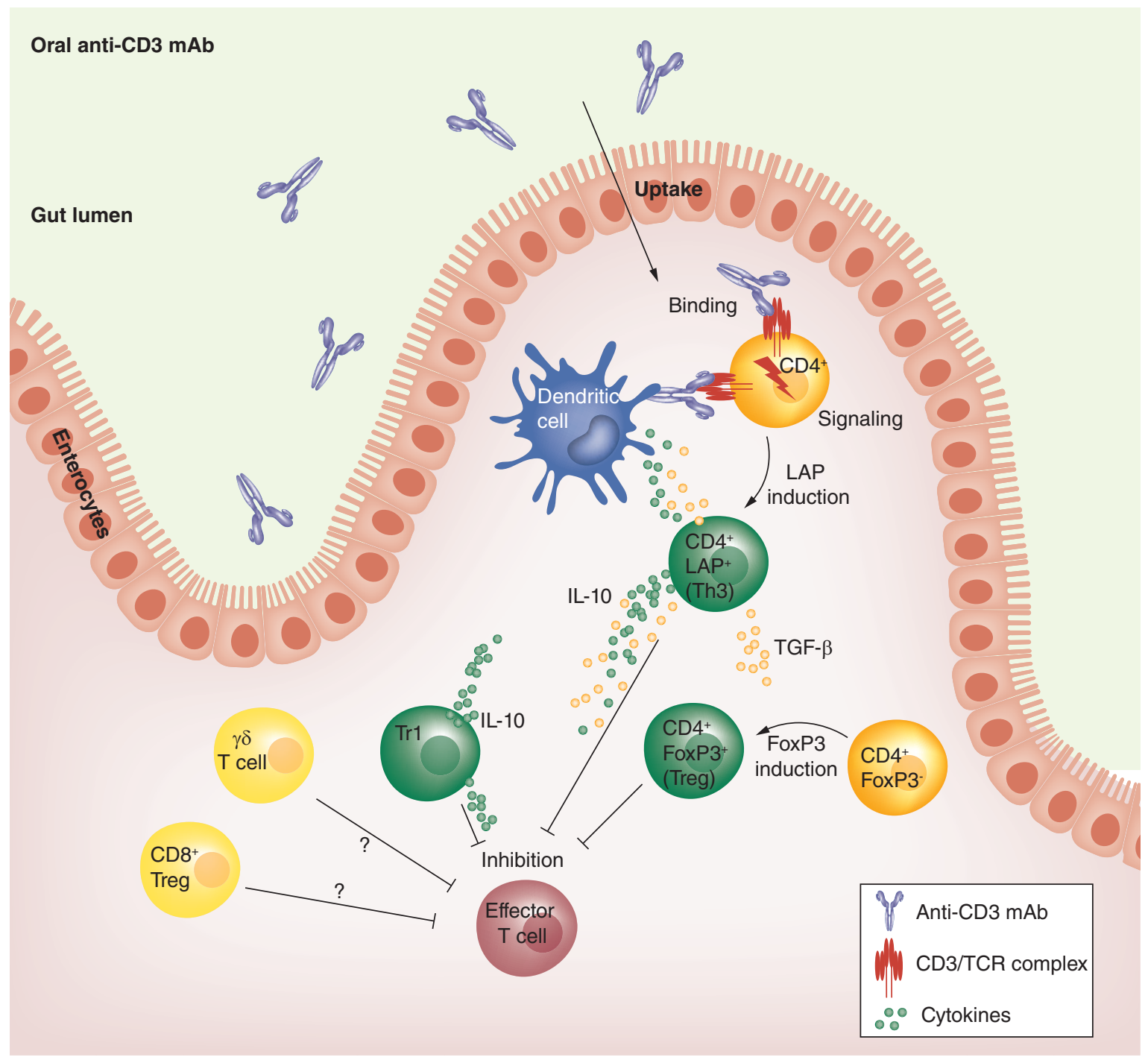

Figure 2. Mechanism of oral anti-CD3 monoclonal antibody induced tolerance. Orally administered anti-CD3 mAb passes the stomach intact and is taken up by the intestinal epithelium. In the lamina propria anti-CD3 mAb binds to the CD3/TCR complex on T cells and FcR binding anti-CD3 mAb can cross-link the CD3/TCR complex via binding to FCR positive antigen presenting cells but this is not required for tolerance induction. Presumably, anti-CD3 mAb binding to $\mathrm{CD}^{+}{ }^{+} \mathrm{T}$ cells in the lamina propria triggers upregulation of latent membrane bound TGF- $\beta$ by the latter, converting them into so-called Th3 cells. The regulatory function of Th3 cells is largely mediated through TGF- $\beta$ but also IL-10 can contribute to the establishment of a tolerogenic microenvironment and lead to inhibition of effector T cells, induction of Tregs and promotion of tolerogenic dendritic cells that also favor induction of Treg subsets such as IL-10 producing $\operatorname{Tr} 1$ cells and FoxP3 ${ }^{+}$Treg. While the role for regulatory $\gamma \delta \mathrm{T}$ cells and $\mathrm{CD} 8^{+} \mathrm{T}$ cells in oral antigen mediated tolerance is already established, a role in oral anti-CD3 mAb-induced tolerance is likely but has not yet been demonstrated.

was derived from the rat antibody YTH12.5. This humanized IgG1 bears a single mutation in the $\gamma 1$ Fc portion to avoid glycosylation and thus inhibit FcR binding [14]. The companies TolerX and GSK were involved in the clinical development of otelixizumab. Visilizumab (Nuvion, HuM291) is a humanized IgG2 antibody that is being clinically developed by PDL BioPharma and is rendered non mitogenic by two point mutations in its $\mathrm{Fc}_{\mathrm{c}}$ region [91]. Foralumab (28F11-AE; NI-0401) is so far the only entirely human anti-CD3 mAb. The completely human origin further decreases side effects that have been previously noted with other humanized anti-CD3 $\mathrm{mAb}$. The Fc portion of this human IgG1 was mutated such that the mAb is non FcR binding in vitro and exhibits only minor cytokine release in vivo while maintaining modulation of the CD3/TCR and T-cell depletion [92]. The reduced release of cytokines after intravenous administration decreases side effects and improves the overall safety 


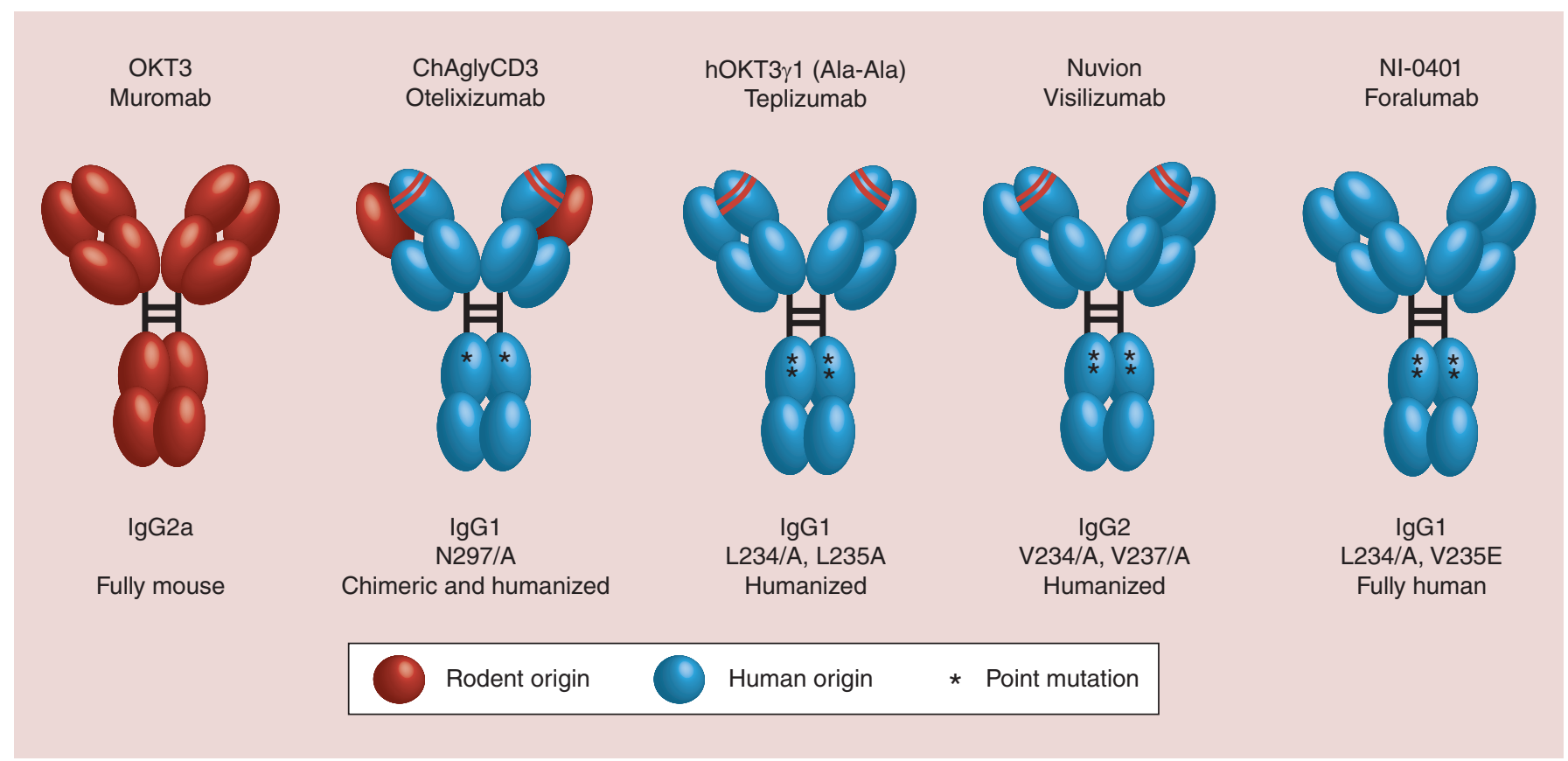

Figure 3. New generation of anti-human CD3 as compared with the mouse anti-human CD3 mAb OKT3.

profile of this anti-CD3 $\mathrm{mAb}$. Foralumab is being clinically developed by Tiziana LIFE SCIENCES.

\section{Clinical trials with intravenous anti-CD3 mAb}

Two Phase I safety trials in renal allograft recipients with acute rejection episodes demonstrated that otelixizumab [93] and teplizumab [94] do not elicit major side-effects. In the year 2000 the first clinical trials with humanized anti-CD3 $\mathrm{mAb}$ were launched to test the tolerogenic activity of anti-CD3 $\mathrm{mAb}$ in T1D. In an American Phase I/II trial, teplizumab treatment of patients with recent onset T1D improved insulin production and metabolic control [95,96]. Similarly, a European Phase II/III study giving up to a total of $64 \mathrm{mg}$ of the anti-CD3 mAb otelixizumab over 6 consecutive days reported a long-lasting therapeutic effect in terms of $\beta$-cell preservation, as measured by C-peptide levels [97,98]. The effect was most significant in patients that had good C-peptide levels at the beginning of the treatment [97,98]. Follow-up studies were designed to test whether a lower dose of teplizumab (two courses of 14 days treatments, each cumulating 5, 6 or $17 \mathrm{mg}$ ) [9] or otelixizumab (3.1 mg cumulated during 8 days) could preserve C-peptide secretion in new-onset T1D patients while decreasing the side effects that were observed in the previous studies. However, the low dose of otelixizumab was nonefficacious [99-101] and the choice of endpoints of the Protégé study testing teplizumab was highly controversial [9]. A post hoc analysis using conventional endpoints found a treatment benefit in patients with higher baseline levels of C-peptide [102]. Also the AbATE study reported that patients with new onset diabetes benefit from treatment with teplizumab for at least 2 years and identified immunologic features at baseline that were significantly different between responders and nonresponders [103]. Teplizumab is currently being tested in preventing onset of T1D in a population 'at-risk' (ClinicalTrials.gov; NCT01030861). A new study on otelixizumab is recruiting T1D patients to identify the concentration with maximal therapeutic effect and minimal side effects (NCT02000817, clinicaltrials.gov). While otelixizumab and teplizumab were foremost tested in patients with T1D, visilizumab and foralumab were mostly studied in IBD [92]. A first Phase I trial, assessing safety and efficacy of visilizumab in patients with severe corticosteroid-refractory ulcerative colitis gave promising results [104]. After reducing the original dose of $15 \mu \mathrm{g} / \mathrm{kg} /$ day for 2 days due to occurring side effects (prolonged lymphopenia) to $10 \mu \mathrm{g} / \mathrm{kg} / \mathrm{day}$ the safety profile was considered acceptable. $84 \%$ of patients showed a clinical response, with $41 \%$ entering clinical remission and $44 \%$ endoscopic remission [104]. A follow-up randomized, double-blind, placebo-controlled trial that was intended to confirm the efficacy of visilizumab for the treatment of IBD (but used only half of the original dose, i.e., $5 \mu \mathrm{g} / \mathrm{kg}$ ) was terminated prematurely because of safety and efficacy concerns [105]. Treatment with a cumulated dose of only $0.7 \mathrm{mg}$ (for a patient weighing $70 \mathrm{~kg}$ ), 
was not only associated with a cytokine release syndrome but also with an increased rate of infection as well as vascular and cardiac symptoms. This was surprising as administration of $48 \mathrm{mg}$ otelixizumab to patients with T1D provoked less side-effects [97]. It was hypothesized that visilizumab's low tolerability as compared with other Fc modified anti-CD3 mAb might be due to a stronger activation of $\mathrm{CD} 3 / \mathrm{TCR}$ signaling [92]. As a consequence the clinical development of visilizumab was halted. Foralumab, the only completely human anti-CD3 $\mathrm{mAb}$, was assessed in a Phase I/II clinical trial in patients with moderate to severe active Crohn's Disease [106]. Intravenous administration of up to $1 \mathrm{mg}$ for 5 days was considered safe with manageable side effects. Even though the power of this study was too limited to assess clinical efficacy, the dose of $1 \mathrm{mg}$ seemed to ameliorate the endoscopic index score while no significant improvement of clinical symptoms as assessed by the Crohn's disease activity index was reported [106].

\section{Clinical trials with oral anti-CD3 mAb}

A Phase I study with healthy subjects showed that repeated oral administration of the anti-CD3 $\mathrm{mAb}$ OKT3 was safe and induced immunological effects [107]. When given orally, this FcR binding antibody did not trigger systemic proinflammatory cytokines, immunogenicity, depletion of $\mathrm{T}$ cells or modulation of the CD3/TCR complex. Oral OKT3 enhanced T-cell proliferation, suppressed Th1 and Th17 responses and led to increased TGF- $\beta /$ IL-10 expression and decreased IL-23/IL-6 expression by dendritic cells [107]. A treatment regime of five-times $1 \mathrm{mg}$ was considered superior to 0.2 or $5 \mathrm{mg}$ [107]. Two single blind randomized placebo controlled Phase IIa studies in patients with treatment resistant chronic hepatitis C infection (HCV) [108] or nonalcoholic steatohepatitis (NASH) and altered glucose metabolism that included subjects with Type 2 diabetes [109], demonstrated that oral CD3 was safe and well tolerated, as measured by blood hematology, chemistry, immunological safety markers and physical signs $[108,109]$. Both studies reported positive effects on disease and immunological markers including an increase of Tregs [108,109].

Thus, mucosal anti-CD3 mAb therapy is an attractive approach for the treatment of inflammatory and autoimmune diseases. Further studies are now required to investigate the therapeutic effect of oral anti-CD3 $\mathrm{mAb}$ and to test nasal administration.

\section{Combination therapies with anti-CD3 mAb to improve safety}

The current generation of anti-CD3 $\mathrm{mAb}$ has highly reduced affinity for $\mathrm{Fc}_{\mathrm{c}}$ receptors and thus shows dramatically reduced side effects as compared with the original FcR binding antibodies derived from rodents. However, T-cell activation and minor cytokine secretion are still observed $[93,95,97,110]$, leading to moderate flu-like syndrome including fever, headache and gastrointestinal symptoms and one clinical trial reported EBV reactivation [111]. Pretreatment with corticosteroids is one of the most widely used strategies to limit infusion-related reactions and has already been tested in combination with intravenous anti-CD3 mAb therapy in the transplantation setting either alone [112] or together with indomethacin [113] or pentoxyfylline [114]. Corticosteroids such as hydrocortisone [115] and methylprednisolone [116] inhibit release of TNF- $\alpha$, IL- 6 and IL-2, thus inhibiting the cytokine release syndrome after infusion with anti-CD3 $\mathrm{mAb}$. As TNF- $\alpha$ plays a major role in triggering anti-CD3 $\mathrm{mAb}$ related side effects specific inhibition of TNF- $\alpha$ using blocking antibodies is an attractive alternative [117]. Indeed, it has been shown that anti-TNF- $\alpha \mathrm{mAb}$ successfully inhibit anti-CD3 $\mathrm{mAb}$ mediated side effects in mice [117] and men [118]. Combination of immunosuppressive drugs with anti-CD3 mAb has given mixed results. Cyclosporine [13], cyclophosphamide [13] and rapamycin [119] have been shown to interfere with anti-CD3 mAbinduced tolerance in the NOD model of autoimmune diabetes while another group reported no negative impact of cyclosporine on efficacy in the EAE model of multiple sclerosis [120]. One explanation might be the observation that cyclosporine, tacrolimus and rapamycin mediate islet toxicity [121] that constitutes out of obvious reasons a major problem in autoimmune diabetes. Another important difference between these studies is the treatment regimen. While the diabetes study was based on a treatment with intravenous anti-CD3 mAb for 5 consecutive days, mice from the EAE study were only treated twice, which achieves in our hands immunosuppression but not tolerance induction. Hence, cyclosporine, tacrolimus and rapamycin might interfere with anti-CD3 mAb-induced tolerance but not with immunosuppression. In conclusion, the use of immunosuppressive agents might interfere with the tolerogenic effect of anti-CD3 $\mathrm{mAb}$ and further research is necessary before considering a combination. A very promising approach to improve safety is oral or nasal administration of anti-CD3 $\mathrm{mAb}$. Clinical data showed promising results in terms of safety and therapeutic effect [107,109]. Future development in anti-CD3 immunotherapy warrants further clinical studies to explore the potential of mucosal anti$\mathrm{CD} 3 \mathrm{mAb}$ therapy for treatment of a wide range of autoimmune and inflammatory diseases in humans. 


\section{Combination therapies with anti-CD3 mAb to improve efficacy}

Many research efforts aim at enhancing anti-CD3 $\mathrm{mAb}$-induced tolerance for therapy of autoimmune diseases [92]. Several nonmutually exclusive strategies are pursued, i.e., increasing the function or number of Tregs and tolerogenic cytokines, better depletion of autoreactive lymphocytes, interfering with proinflammatory processes and disease-specific approaches that improve function or regeneration of the target organ. Induction of antigen-specific or nonspecific Tregs is an attractive approach for treating autoimmunity [122] and has the potential to improve the therapeutic effect of anti-CD3 $\mathrm{mAb}$, as in the case of mucosal administration of antigen [26]. Oral administration of autoantigen or anti-CD3 $\mathrm{mAb}$ has been shown to induce tolerance multiple animal models of autoimmune diseases [26,85]. Coadministration of oral insulin to diabetic NOD mice improved and prolonged the therapeutic efficacy of anti-CD3 mAb therapy [123]. Interestingly, preexisting autoantibodies predicted the efficacy of this combination therapy [123]. Takiishi et al. went further and combined anti-CD3 $\mathrm{mAb}$ with mucosal delivery of biologically contained Lactococcus lactis genetically modified to secrete proinsulin together with the immunomodulatory cytokine IL-10, inducing longterm tolerance in diabetic NOD mice [124]. While oral tolerance induction is associated with $\mathrm{LAP}^{+}$Treg (Th3 cells), nasal administration of antigen relies on induction of IL-10 producing Treg (Tr1) [26]. Intranasal delivery of insulin also enhances the therapeutic effect of anti-CD3 $\mathrm{mAb}$ in NOD mice [125]. Also combination of intravenous anti-CD3 $\mathrm{mAb}$ with administration of a GAD65 expressing plasmid gave promising results in autoimmune diabetes [125]. The combination of oral or nasal antigen with intravenous anti-CD3 $\mathrm{mAb}$ has not yet been tested in the clinic or in other autoimmune diseases but has good potential for clinical translation. Similarly, we hypothesize that oral and nasal anti-CD3 $\mathrm{mAb}$ are likely to enhance the tolerogenic effect of intravenous anti-CD3 $\mathrm{mAb}$ by inducing Treg. Anti-CD3 mAb have been intensively studied in T1D and an important point that needs to be considered in T1D is that once diabetes is diagnosed a big portion of insulin producing $\beta$-cells is already destroyed and anti-CD3 $\mathrm{mAb}$ therapy will not be sufficient to reverse diabetes once the autoimmune process has progressed too far. Thus, combination of anti-CD3 mAb therapy with methods that restore insulin production by recovery, expansion or replacement of $\beta$-cells is an attractive approach. Exendin- 4 is a glucagon-like peptide-1 receptor agonist that stimulates $\beta$-cell proliferation and inhibits apoptosis and it increased remission from diabetes in NOD mice treated with anti-CD3 $\mathrm{mAb}$ by enhancing the recovery of the residual islets [126]. This combinatorial approach may be useful in treatment of patients with new-onset T1D that still harbor a sufficient amount of functional $\beta$-cells. In cases of extremely low $\beta$-cell mass, islet transplantations might be required in combination with immunotherapy. The combination of teplizumab with other immunosuppressive drugs in the setting of pancreatic islet transplantation showed promising results [127,128]. However, these studies only assessed the benefit of anti-CD3 $\mathrm{mAb}$ as immunosuppressive agents. Recent findings show that anti-CD3 mAb can induce operational tolerance in the setting of islet allografts in mice if administered some days after transplantation, when $\mathrm{T}$ cells have already been primed against the allo-antigens [45]. Another publication showed that combination of anti-CD3 mAb with transplantation of embryonic pancreatic precursors has a synergistic effect on recovery of NOD mice from diabetes [129]. Inhibition of inflammation by specifically targeting of autoreactive $\mathrm{T}$ cells or neutralizing of proinflammatory cytokines seems to be a particularly promising approach. The selective $\mathrm{S}_{1} \mathrm{P}_{1}$ receptor modulator ponesimod sequesters $\mathrm{T}$ cells within lymph nodes. Administration of ponesimod to diabetic NOD mice followed by anti-CD3 mAb treatment, started a few days before discontinuation of ponesimod, induced long-lasting disease remission in all treated mice [130]. IL- $1 \beta$ is an interesting therapeutical target in T1D as it has been shown to inhibit insulin secretion and synthesis and to affect $\beta$-cell viability [131]. Ablamunits et al. found synergistic reversal of autoimmune diabetes and enhanced immune regulation in NOD mice treated with anti-CD3 mAb together with IL-1 receptor antagonist [132]. Combination of anti-CD3 $\mathrm{mAb}$ with anti-TNF $\mathrm{mAbs}$ achieved synergistic therapeutic effect in collagen-induced arthritis (CIA), inhibiting progression of disease [133,134]. Also in kidney transplantation pairing anti- $\mathrm{CD} 3 \mathrm{mAb}$ with antiTNF mAb improved the clinical outcome [135] and it is has been proposed that this combination achieves superior depletion of pathogenic $T$ cells [92]. It will be interesting to assess efficacy of these combinatorial approaches in the clinical setting. It will be important to test if these drugs can also increase the efficacy of oral or nasal anti-CD3 mAb. No combination studies with mucosally administered anti-CD3 $\mathrm{mAb}$ have been performed so far.

\section{Conclusion \& future perspective}

Non-FcR binding anti-CD3 $\mathrm{mAb}$ are promising modalities for treatment of autoimmune and inflammatory diseases. First clinical trials investigating 
intravenous administration of teplizumab, otelixizumab or visilizumab have been encouraging with positive clinical responses [95-98,104]. Follow-up trials that did not recapitulate the initial success [99-101,105], most probably due to the altered studies protocols (i.e., reduced dosing, different end points), clearly point out the challenges of the clinical development of anti-CD3 mAb: finding the best dose, treating at the right time-point and identifying biomarkers that predict treatment success. A significant progress was the identification of baseline metabolic (HbAlc and insulin use) and immunologic features distinguishing responders from nonresponders in the AbATE study that showed C-peptide preservation in T1D patients, 2 years after teplizumab treatment [103]. The ongoing AbATE follow-up study (ClinicalTrials.gov; NCT02067923) is further investigating C-peptide changes in treated patients versus the control group from the AbATE trial. Teplizumab is also being tested in prevention of T1D in a population 'at-risk' (ClinicalTrials.gov; NCT01030861) and a clinical trial on otelixizumab is currently recruiting T1D patients to pinpoint the concentration with maximal therapeutic effect and minimal side effects (NCT02000817, clinicaltrials.gov). It will be interesting to see if previously reported biomarkers that distinguish responders from nonresponders will be confirmed and if new biomarkers can be identified. With the encouraging progress in T1D it is likely that intravenous anti-CD3 $\mathrm{mAb}$ therapy will also be further explored in other autoimmune diseases.

Multiple preclinical studies have demonstrated that oral (or nasal) administration of anti-CD3 $\mathrm{mAb}$ can be used effectively for the prevention and/or treatment of disease in animal models of autoimmune diseases $[75-77,84,89]$ and inflammatory disorders [47,79], foremost by induction of Tregs. There were no detectable side effects such as cytokine release syndrome or immunogenicity [107-109]. The strategy to induce oral tolerance by anti-CD3 $\mathrm{mAb}$ represents an exciting and novel avenue for treatment of autoimmune diseases due to the very good safety profile and the highvariety of potential applications. A clinical trial testing oral and nasal administration of foralumab for treatment of autoimmune disease and chronic inflammation is being planned by Tiziana Life Sciences.

Preclinical data suggest that intravenous administration of anti-CD3 $\mathrm{mAb}$ is more suitable to treat active autoimmune disease while oral anti-CD3 $\mathrm{mAb}$ is more potent in preventing disease and has considerably less side-effects. Hence, the route of administration will differ according to the respective application and the patient's immune status. The combination of both routes (intravenous and mucosal) might be an attractive strategy to be explored. More preclinical and clinical studies are necessary to better understand mechanisms underlying intravenous and oral antiCD3 mAb-induced tolerance, what distinguishes the different clones of anti-CD3 $\mathrm{mAb}$ in terms of therapeutic effect and side effects and how we can enhance their therapeutic effect. Preclinical studies have demonstrated a high potential of combining intravenous or mucosal anti-CD3 mAb with other immunomodulatory drugs to produce additive or synergistic therapeutic effect [77,123-126,130,132-134]. Now, clinical trials are needed to further explore the most promising combination therapies. The obvious choice would be combination of anti-CD3 mAb with FDA approved drugs that are already being used as gold standard for the treatment of respective inflammatory and autoimmune diseases. Further mechanistic studies will address the impact of the microenvironment on antiCD3 mAb-induced tolerance and open the door to new therapeutic combinations.

Also from an industry perspective anti-CD3 $\mathrm{mAb}$ therapy represents an attractive strategy for a wide range of autoimmune and inflammatory diseases. Thanks to modern technologies involving chimerization and humanization of rodent antibodies for clinical use, side effects triggered by $\mathrm{mAbs}$ have been drastically reduced $[10,136]$. An increasing number of humanized antibodies is being approved by FDA as drugs [137] and the commercial impact is considerable, with annual sales exceeding multibillion dollars in recent years [138].

In short, anti-CD3 $\mathrm{mAb}$ have the potential to revolutionize therapy of chronic inflammatory and autoimmune diseases with high unmet medical needs such as IBD, NASH, T1D and MS.

\section{Financial \& competing interests disclosure}

Howard L Weiner received consulting fees and/or research support from several companies including Serono, Biogen, Therapix, Novartis, Tiziana Life Sciences, Genzyme and Teva. Howard L Weiner receives funding from the NIH (R01 Al43458, entitled "Mechanisms of the Induction of Oral Tolerance". The authors have no other relevant affiliations or financial involvement with any organization or entity with a financial interest in or financial conflict with the subject matter or materials discussed in the manuscript apart from those disclosed.

No writing assistance was utilized in the production of this manuscript.

\section{Open access}

This work is licensed under the Attribution-NonCommercialNoDerivatives 4.0 Unported License. To view a copy of this license, visit http://creativecommons.org/licenses/by-nc$\mathrm{nd} / 4.0 /$ 
Executive summary

Background

- 1979: discovery of the first anti-human CD3 monoclonal antibody (anti-CD3 mAb) OKT3/muromab.

- 1986: US FDA approval of OKT3 as immunosuppressant for inhibiting transplant rejection but rapid replacement by better immunosuppressive drugs with less side effects.

- 1987: development of the first anti-mouse anti-CD3 mAb (145-2C11).

- 1993: generation of the first humanized, non-Fc receptor binding anti-CD3 mAb with reduced side effects.

- 1994: discovery that anti-CD3 mAb can induce long-lasting tolerance in a mouse model of autoimmune diabetes.

Tregs in autoimmune diseases

- Most autoimmune diseases are due to aberrations in Tregs.

- Anti-CD3 mAb therapy is associated with an increased number and function of different subsets of Treg: FoxP3+ Treg, IL-10 secreting Tr1 and membrane TGF- $\beta$ expressing Th3 cells.

Anti-CD3 mAb in animal models

- Intravenous administration of anti-CD3 mAb

- Repeated intravenous administration of anti-CD3 mAb induces remission from disease in multiple mouse models of autoimmunity.

= Intravenous anti-CD3 mAb therapy is more efficient reversing than preventing disease.

- How does intravenous administration of anti-CD3 mAb induce tolerance in autoimmune diseases?

- Intravenous anti-CD3 mAb-induced tolerance is a multistep process involving several nonmutually exclusive mechanisms that restore the balance between Treg and effector T cells.

- Binding of intravenous anti-CD3 mAb to the CD3/TCR complex on T cells triggers TCR modulation through internalization or shedding, TCR signaling, anergy and/or apoptosis.

- Effector T cells are more susceptible to anti-CD3 mAb-induced apoptosis than Treg.

= TGF- $\beta$ derived from apoptotic cells and phagocytosing macrophages is essential for anti-CD3 mAb-induced tolerance.

- Generation of gut tropic IL-10 secreting Treg likely contributes to the therapeutic effect of intravenous anti-CD3 mAb.

New mouse models for testing human specific anti-CD3 mAb

- Anti-CD3 mAb are species specific.

- Transgenic NOD mice expressing the human CD3 epsilon chain are a preclinical model for testing human anti$\mathrm{CD} 3 \mathrm{mAb}$ in autoimmune diabetes.

- NOD/SCID IL2 $\gamma \mathrm{C}^{\prime-}$ (NSG) mice engrafted with human hematopoietic stem cells makes preclinical mechanistic studies of human anti-CD3 mAb in vivo possible.

Oral administration of anti-CD3 mAb inmice

- Oral administration of anti-CD3 mAb prevents autoimmunity and alleviates ongoing disease.

- Oral anti-CD3 mAb shows promise in treatment of inflammatory disorders.

How does oral anti-CD3 mAb induce tolerance?

- Oral anti-CD3 mAb-induced tolerance relies mostly on Th3 cells.

- Tr1 cells contribute to tolerance in the colitis model.

- Th3 cells inhibit follicular T helper cell, Th1, Th2 and likely Th17 responses, depending on the disease model.

Nasal administration of anti-CD3 mAb

- Nasal administration of anti-CD3 mAb prevents and improves autoimmunity in several mouse models.

- Nasal anti-CD3 mAb-induced tolerance depends on IL-10.

Clinical development of anti-human anti-CD3 mAbs

- The clinical development of anti-CD3 mAb was relaunched with the generation of non-Fc receptor binding, chimeric/humanized/human anti-CD3 mAb with reduced side effects (otelixizumab, teplizumab, visilizumab and foralumab).

Clinical trials with intravenous anti-CD3 mAb

- Otelixizumab and teplizumab showed promising results in patients with recent onset of Type 1 diabetes (T1D).

- A dose finding study with otelixizumab in T1D was launched after negative results from a clinical trial studying decreased dosing.

- Baseline metabolic and immunological markers that distinguish responders from non-responders were identified

- Foralumab and visilizumab were tested in patients with inflammatory bowel disease (IBD) with encouraging results.

- The clinical development of visilizumab was stopped due to safety concerns in a follow-up study.

- Otelixizumab, teplizumab and foralumab continue their clinical development. 
Executive summary (cont.)

\section{Clinical trials with oral anti-CD3 mAb}

- Oral administration of anti-CD3 mAb was shown to be safe in three independent Phase I and II clinical trials.

- Oral anti-CD3 mAb-induced anti-inflammatory effects in healthy subjects and patients with chronic hepatitis C infection or NASH.

Combination therapies with anti-CD3 mAb to improve safety

- Immunosuppressive agents reduce side effects triggered by intravenous anti-CD3 mAb therapy.

- Some immunosuppressive agents interfered with anti-CD3 mAb-induced tolerance.

- Combination of intravenous anti-CD3 mAb with anti-TNF $\alpha$ mAb or corticosteroids looks promising.

Combination therapies with anti-CD3 mAb to improve efficacy

- Administration of oral or nasal auto-antigen improved the therapeutic effect of intravenous anti-CD3 mAb.

- Disease specific strategies to preserve, repair or replace the target organ are interesting.

- Neutralization of proinflammatory cytokines or targeting of effector T cells enhanced intravenous anti-CD3 mAb-induced tolerance.

\section{Future perspective}

- A dose finding clinical trial investigating intravenous otelixizumab in patients with Type 1 diabetes in ongoing.

- Teplizumab (iv.) is currently being tested in preventing Type 1 diabetes in 'at-risk' patients.

- A clinical trial is programmed to asses safety and efficacy of oral administration of foralumab.

- Combination of anti-CD3 mAb with immunomodulatory drugs has promising therapeutic potential.

\section{References}

Papers of special note have been highlighted as:

- of interest; $\bullet$ • of considerable interest

1 Kung P, Goldstein G, Reinherz EL, Schlossman SF. Monoclonal antibodies defining distinctive human T cell surface antigens. Science 206(4416), 347-349 (1979).

2 Hooks MA, Wade CS, Millikan WJ. Muromonab CD-3: a review of its pharmacology, pharmacokinetics, and clinical use in transplantation. Pharmacotherapy 11(1), 26-37 (1991).

3 Weinshenker BG, Bass B, Karlik S, Ebers GC, Rice GP. An open trial of OKT3 in patients with multiple sclerosis. Neurology 41(7), 1047-1052 (1991).

4 Chatenoud L, Baudrihaye MF, Chkoff N, Kreis H, Goldstein G, Bach J-F. Restriction of the human in vivo immune response against the mouse monoclonal antibody OKT3. J. Immunol. 137(3), 830-838 (1986).

5 Lobo PI, Patel HC. Murine monoclonal IgG antibodies: differences in their IgG isotypes can affect the antibody effector activity when using human cells. Immunol. Cell Biol. 75(3), 267-274 (1997).

6 Sgro C. Side-effects of a monoclonal antibody, muromonab CD3/orthoclone OKT3: bibliographic review. Toxicology 105(1), 23-29 (1995).

7 Leo O, Foo M, Sachs DH, Samelson LE, Bluestone JA. Identification of a monoclonal antibody specific for a murine T3 polypeptide. Proc. Natl Acad. Sci. USA 84(5), 1374-1378 (1987).

8 Chatenoud L, Thervet E, Primo J, Bach J-F. AntiCD3 antibody induces long-term remission of overt autoimmunity in nonobese diabetic mice. Proc. Natl Acad. Sci. USA 91(1), 123-127 (1994).

- $\quad$ First study showing that intravenous anti-CD3 $\mathrm{mAb}$ induce long-lasting tolerance in a mouse model of autoimmunity.
9 Chatenoud L, Waldmann H. CD3 monoclonal antibodies: a first step towards operational immune tolerance in the clinic. Rev. Diabet. Stud. 9(4), 372-381 (2012).

10 Almagro JC, Fransson J. Humanization of antibodies. Front. Biosci. 13, 1619-1633 (2008).

11 Ferran C, Sheehan K, Dy M et al. Cytokine-related syndrome following injection of anti-CD3 monoclonal antibody: Further evidence for transient in vivo $\mathrm{T}$ cell activation. Eur. J. Immunol. 20(3), 509-515 (1990).

12 Hirsch R, Eckhaus M, Auchincloss H, Sachs DH, Bluestone JA. Effects of in vivo administration of anti-T3 monoclonal antibody on $\mathrm{T}$ cell function in mice. I. Immunosuppression of transplantation responses. J. Immunol. 140(11), 3766-3772 (1988).

13 Chatenoud L, Primo J, Bach J-F. CD3 antibody-induced dominant self tolerance in overtly diabetic NOD mice. J. Immunol. 158(6), 2947-2954 (1997).

14 Bolt S, Routledge E, Lloyd I et al. The generation of a humanized, non-mitogenic CD3 monoclonal antibody which retains in vitro immunosuppressive properties. Eur. J. Immunol. 23(2), 403-411 (1993).

15 Alegre ML, Peterson LJ, Xu D et al. A non-activating "humanized" anti-CD3 monoclonal antibody retains immunosuppressive properties in vivo. Transplantation 57(11), 1537-1543 (1994).

16 Chatenoud L, Bluestone JA. CD3-specific antibodies: a portal to the treatment of autoimmunity. Nat. Rev. Immunol. 7(8), 622-632 (2007).

- Detailed and comprehensible review on mechanism underlying intravenous anti-CD3 $\mathrm{mAb}$-induced tolerance.

17 Yuan X, Cheng G, Malek TR. The importance of regulatory T-cell heterogeneity in maintaining self-tolerance. Immunol. Rev. 259(1), 103-114 (2014).

18 Burzyn D, Benoist C, Mathis D. Regulatory T cells in nonlymphoid tissues. Nat. Immunol. 14(10), 1007-1013 (2013). 
19 Hsieh C-S, Liang Y, Tyznik AJ, Self SG, Liggitt D, Rudensky AY. Recognition of the peripheral self by naturally arising CD25 + CD4 + T cell receptors. Immunity 21(2), 267-277 (2004).

20 Jordan MS, Boesteanu A, Reed AJ et al. Thymic selection of $\mathrm{CD} 4+\mathrm{CD} 25+$ regulatory $\mathrm{T}$ cells induced by an agonist selfpeptide. Nat. Immunol. 2(4), 301-306 (2001).

21 Sakaguchi S, Sakaguchi N, Asano M, Itoh M, Toda M. Immunologic self-tolerance maintained by activated $\mathrm{T}$ cells expressing IL-2 receptor alpha-chains (CD25). Breakdown of a single mechanism of self-tolerance causes various autoimmune diseases. J. Immunol. 155(3), 1151-1164 (1995).

22 Fontenot JD, Gavin MA, Rudensky AY. Foxp3 programs the development and function of $\mathrm{CD} 4+\mathrm{CD} 25+$ regulatory T cells. Nat. Immunol. 4(4), 330-336 (2003).

23 Ziegler SF. FOXP3: of mice and men. Annu. Rev. Immunol. 24, 209-226 (2006).

24 Bilate AM, Lafaille JJ. Induced CD4+Foxp3+ regulatory T cells in immune tolerance. Annu. Rev. Immunol. 30, 733-758 (2012).

25 Pot C, Apetoh L, Kuchroo VK. Seminars in immunology. Semin. Immunol. 23(3), 202-208 (2011).

26 Weiner HL, da Cunha AP, Quintana F, Wu H. Oral tolerance. Immunol. Rev. 241(1), 241-259 (2011).

- Detailed and comprehensible review on oral tolerance induction using oral antigen or anti-CD3 $\mathrm{mAb}$.

27 Tran DQ. TGF-: the sword, the wand, and the shield of FOXP3+ regulatory T cells. J. Mol. Cell Biol. 4(1), 29-37 (2012).

28 Peterson RA. Regulatory T-cells: diverse phenotypes integral to immune homeostasis and suppression. Toxicol. Pathol. 40(2), 186-204 (2012).

29 Asseman C, Mauze S, Leach MW, Coffman RL, Powrie F. An essential role for interleukin 10 in the function of regulatory $\mathrm{T}$ cells that inhibit intestinal inflammation. J. Exp. Med. 190(7), 995-1004 (1999).

30 Powrie F, Carlino J, Leach MW, Mauze S, Coffman RL. A critical role for transforming growth factor-beta but not interleukin 4 in the suppression of $\mathrm{T}$ helper type 1-mediated colitis by CD45RB (low) CD4+ T cells. J. Exp. Med. 183(6), 2669-2674 (1996).

31 Collison LW, Workman CJ, Kuo TT et al. The inhibitory cytokine IL-35 contributes to regulatory T-cell function. Nature 450 (7169), 566-569 (2007).

32 Grossman WJ, Verbsky JW, Tollefsen BL, Kemper C, Atkinson JP, Ley TJ. Differential expression of granzymes $\mathrm{A}$ and $\mathrm{B}$ in human cytotoxic lymphocyte subsets and $\mathrm{T}$ regulatory cells. Blood 104(9), 2840-2848 (2004).

33 Hänig J, Lutz MB. Suppression of mature dendritic cell function by regulatory $\mathrm{T}$ cells in vivo is abrogated by CD 40 licensing. J. Immunol. 180(3), 1405-1413 (2008).

34 Liang B, Workman C, Lee J et al. Regulatory T cells inhibit dendritic cells by lymphocyte activation gene- 3 engagement of MHC class II. J. Immunol. 180(9), 5916-5926 (2008).

35 Schmitt EG, Williams CB. Generation and function of induced regulatory T cells. Front. Immunol. 4, 152 (2013).
36 Brusko TM, Putnam AL, Bluestone JA. Human regulatory $T$ cells: role in autoimmune disease and therapeutic opportunities. Immunol. Rev. 223, 371-390 (2008).

37 Tran GT, Carter N, He XY et al. Reversal of experimental allergic encephalomyelitis with non-mitogenic, non-depleting anti-CD3 $\mathrm{mAb}$ therapy with a preferential effect on $\mathrm{T}(\mathrm{h}) 1$ cells that is augmented by IL-4. Int. Immunol. 13(9), 1109-1120 (2001).

38 Kohm AP, Williams JS, Bickford AL et al. Treatment with Nonmitogenic Anti-CD3 Monoclonal Antibody Induces CD4+ T Cell Unresponsiveness and Functional Reversal of Established Experimental Autoimmune Encephalomyelitis. J. Immunol. 174(8), 4525-4534 (2005).

39 Lúdvíksson BR, Ehrhardt RO, Strober W. TGFbeta production regulates the development of the 2,4,6-trinitrophenol-conjugated keyhole limpet hemocyanininduced colonic inflammation in IL-2-deficient mice. J. Immunol. 159(7), 3622-3628 (1997).

40 Hughes C, Wolos JA, Giannini EH, Hirsch R. Induction of $\mathrm{T}$ helper cell hyporesponsiveness in an experimental model of autoimmunity by using nonmitogenic anti-CD3 monoclonal antibody. J. Immunol. 153(7), 3319-3325 (1994).

41 Blazar BR, Taylor PA, Vallera DA. In vivo or in vitro antiCD3 epsilon chain monoclonal antibody therapy for the prevention of lethal murine graft-versus-host disease across the major histocompatibility barrier in mice. J. Immunol. 152(7), 3665-3674 (1994).

42 Blazar BR, Jenkins MK, Taylor PA et al. Anti-CD3 epsilon $\mathrm{F}(\mathrm{ab}$ ')2 fragments inhibit $\mathrm{T}$ cell expansion in vivo during graft-versus-host disease or the primary immune response to nominal antigen. J. Immunol. 159(12), 5821-5833 (1997).

43 Nicolls MR, Aversa GG, Pearce NW et al. Induction of longterm specific tolerance to allografts in rats by therapy with an anti-CD3-like monoclonal antibody. Transplantation 55(3), 459-468 (1993).

44 Plain KM, Chen J, Merten S, He XY, Hall BM. Induction of specific tolerance to allografts in rats by therapy with nonmitogenic, non-depleting anti-CD3 monoclonal antibody: association with TH2 cytokines not anergy. Transplantation 67(4), 605-613 (1999).

45 You S, Zuber J, Kuhn C et al. Induction of Allograft Tolerance by Monoclonal CD3 Antibodies: A Matter of Timing. Am. J. Transplant. 12(11), 2909-2919 (2012).

46 Goto R, You S, Zaitsu M, Chatenoud L, Wood KJ. Delayed anti-CD3 therapy results in depletion of alloreactive T cells and the dominance of Foxp3+CD4+ graft infiltrating cells. Am. J. Transplant. 13(7), 1655-1664 (2013).

47 Kita T, Yamashita T, Sasaki N et al. Regression of atherosclerosis with anti-CD3 antibody via augmenting a regulatory T-cell response in mice. Cardiovasc. Res. 102(1), 107-117 (2014).

48 Chatenoud L. CD3-specific antibodies restore self-tolerance: mechanisms and clinical applications. Curr. Opin. Immunol. 17(6), 632-637 (2005).

49 Tunnacliffe A, Olsson C, la Hera de A. The majority of human CD3 epitopes are conferred by the epsilon chain. Int Immunol. 1(5), 546-550 (1989). 
50 Salmerón A, Sánchez-Madrid F, Ursa MA, Fresno M, Alarcón B. A conformational epitope expressed upon association of CD3-epsilon with either CD3-delta or CD3gamma is the main target for recognition by anti-CD3 monoclonal antibodies. J. Immunol. 147(9), 3047-3052 (1991).

51 You S, Candon S, Kuhn C, Bach J-F, Chatenoud L. word. Adv. Immunol. 100, 13-37 (2008).

52 Chatenoud L, Baudrihaye MF, Kreis H, Goldstein G, Schindler J, Bach J-F. Human in vivo antigenic modulation induced by the anti-T cell OKT3 monoclonal antibody. Eur. J. Immunol. 12(11), 979-982 (1982).

53 Smith JA, Tso JY, Clark MR, Cole MS, Bluestone JA. Nonmitogenic anti-CD3 monoclonal antibodies deliver a partial T cell receptor signal and induce clonal anergy. J. Exp. Med. 185(8), 1413-1422 (1997).

54 Penaranda C, Tang Q, Bluestone JA. Anti-CD3 therapy promotes tolerance by selectively depleting pathogenic cells while preserving regulatory T cells. J. Immunol. 187(4), 2015-2022 (2011).

55 Valle A, Barbagiovanni G, Jofra T et al. Heterogeneous CD3 expression levels in differing $\mathrm{T}$ cell subsets correlate with the in vivo anti-CD3-mediated $\mathrm{T}$ cell modulation. J. Immunol. 194(5), 2117-2127 (2015).

56 Herold KC, Burton JB, Francois F, Poumian-Ruiz E, Glandt $\mathrm{M}$, Bluestone JA. Activation of human T cells by FcR nonbinding anti-CD3 mAb, hOKT3gamma1 (Ala-Ala). J. Clin. Invest. 111(3), 409-418 (2003).

57 Kuhn C, You S, Valette F et al. Human CD3 Transgenic Mice: Preclinical Testing of Antibodies Promoting Immune Tolerance. Sci. Transl. Med. 3(68), 68ra10-68ra10 (2011).

58 Perruche S, Zhang P, Liu Y, Saas P, Bluestone JA, Chen W. CD3-specific antibody-induced immune tolerance involves transforming growth factor-beta from phagocytes digesting apoptotic T cells. Nat. Med. 14(5), 528-535 (2008).

59 Belghith M, Bluestone JA, Barriot S, Mégret J, Bach J-F, Chatenoud L. TGF-beta-dependent mechanisms mediate restoration of self-tolerance induced by antibodies to CD3 in overt autoimmune diabetes. Nat. Med. 9(9), 1202-1208 (2003).

60 Travis MA, Sheppard D. TGF- $\beta$ activation and function in immunity. Annu. Rev. Immunol. 32, 51-82 (2014).

61 Chen W, Jin W, Hardegen $\mathrm{N}$ et al. Conversion of peripheral $\mathrm{CD} 4+\mathrm{CD} 25$ - naive $\mathrm{T}$ cells to $\mathrm{CD} 4+\mathrm{CD} 25+$ regulatory $\mathrm{T}$ cells by TGF-beta induction of transcription factor Foxp3. J. Exp. Med. 198(12), 1875-1886 (2003).

62 Kehrl JH, Wakefield LM, Roberts AB et al. Production of transforming growth factor beta by human $\mathrm{T}$ lymphocytes and its potential role in the regulation of $\mathrm{T}$ cell growth. J. Exp. Med. 163(5), 1037-1050 (1986).

63 Steinman RM, Hawiger D, Nussenzweig MC. Tolerogenic dendritic cells. Annu. Rev. Immunol. 21, 685-711 (2003).

64 You S, Leforban B, Garcia C, Bach J-F, Bluestone JA, Chatenoud L. Adaptive TGF-beta-dependent regulatory $\mathrm{T}$ cells control autoimmune diabetes and are a privileged target of anti-CD3 antibody treatment. Proc. Natl Acad. Sci. USA 104(15), 6335-6340 (2007).
65 Esplugues E, Huber S, Gagliani N et al. Control of T. Nature 475(7357), 514-518 (2012).

66 Waldron-Lynch F, Henegariu O, Deng S et al. Teplizumab induces human gut-tropic regulatory cells in humanized mice and patients. Sci. Transl. Med. 4(118), 118ra12 (2012).

67 Vossenkämper A, Hundsrucker C, Page K et al. A CD3specific antibody reduces cytokine production and alters phosphoprotein profiles in intestinal tissues from patients with inflammatory bowel disease. Gastroenterology 147(1), 172-183 (2014).

68 Shouval DS, Ouahed J, Biswas A et al. Interleukin 10 receptor signaling: master regulator of intestinal mucosal homeostasis in mice and humans. Adv. Immunol. 122, 177-210 (2014).

69 Yu QT, Saruta M, Papadakis KA. Visilizumab induces apoptosis of mucosal $\mathrm{T}$ lymphocytes in ulcerative colitis through activation of caspase 3 and 8 dependent pathways. Clin. Immunol. 127(3), 322-329 (2008).

70 Ablamunits V, Bisikirska B, Herold KC. Acquisition of regulatory function by human CD8(+) T cells treated with anti-CD3 antibody requires TNF. Eur. J. Immunol. 40(10), 2891-2901 (2010).

71 Ochi $\mathrm{H}$, Abraham M, Ishikawa $\mathrm{H}$ et al. Oral CD3-specific antibody suppresses autoimmune encephalomyelitis by inducing CD4+CD25-LAP+ T cells. Nat. Med. 12(6), 627-635 (2006).

-• First study demonstrating that oral administration of anti-CD3 $\mathrm{mAb}$ induces tolerance in a mouse model of autoimmunity, including a detailed analysis of the underlying mechanisms that include generation of Th3 cells that are characterized by their expression of membrane bound TGF- $\beta$.

72 Apostolou I, Boehmer von $\mathrm{H}$. In vivo instruction of suppressor commitment in naive T cells. J. Exp. Med. 199(10), 1401-1408 (2004).

73 Kretschmer K, Apostolou I, Hawiger D, Khazaie K, Nussenzweig MC, Boehmer von $\mathrm{H}$. Inducing and expanding regulatory $\mathrm{T}$ cell populations by foreign antigen. Nat. Immunol. 6(12), 1219-1227 (2005).

74 Zhang X. Recovery from experimental allergic encephalomyelitis is TGF- dependent and associated with increases in CD4+LAP+ and CD4+CD25+ T cells. Int. Immunol. 18(4), 495-503 (2006).

75 Ishikawa H, Ochi H, Chen ML, Frenkel D, Maron R, Weiner HL. Inhibition of Autoimmune Diabetes by Oral Administration of Anti-CD3 Monoclonal Antibody. Diabetes 56(8), 2103-2109 (2007).

76 Wu HY, Quintana FJ, Weiner HL. Nasal Anti-CD3 Antibody Ameliorates Lupus by Inducing an IL-10-Secreting CD4+CD25-LAP+ Regulatory T Cell and Is Associated with Down-Regulation of IL-17+CD4+ICOS+CXCR5+ Follicular Helper T Cells. J. Immunol. 181(9), 6038-6050 (2008).

-. First study demonstrating that nasal administration of anti-CD3 $\mathrm{mAb}$ induces tolerance in a mouse model of autoimmunity, by a mechanism different from oral administration. 
77 Wu HY, Maron R, Tukpah AM, Weiner HL. Mucosal anti-CD3 monoclonal antibody attenuates collageninduced arthritis that is associated with induction of LAP+ regulatory $\mathrm{T}$ cells and is enhanced by administration of an emulsome-based Th2-skewing adjuvant. J. Immunol. 185(6), 3401-3407 (2010).

78 Forster K, Goethel A, Chan CWT, Zanello G, Streutker C, Croitoru K. An oral CD3-Specific antibody suppresses T-cell-induced colitis and alters cytokine responses to T-cell activation in mice. Gastroenterology 143(5), 1298-1307 (2012).

79 Ilan Y, Maron R, Tukpah A-M et al. Induction of regulatory $T$ cells decreases adipose inflammation and alleviates insulin resistance in ob/ob mice. Proc. Natl Acad. Sci. USA 107(21), 9765-9770 (2010).

80 Sasaki N, Yamashita T, Takeda M et al. Oral anti-CD3 antibody treatment induces regulatory $\mathrm{T}$ cells and inhibits the development of atherosclerosis in mice. Circulation 120(20), 1996-2005 (2009).

81 Miyamoto K, Kingsley CI, Zhang X et al. The ICOS molecule plays a crucial role in the development of mucosal tolerance. J. Immunol. 175(11), 7341-7347 (2005).

82 Peron JPS, de Oliveira APL, Rizzo LV. Autoimmunity Reviews. Autoimmun. Rev. 9(1), 1-4 (2009).

83 Slavin AJ, Maron R, Weiner HL. Mucosal administration of IL-10 enhances oral tolerance in autoimmune encephalomyelitis and diabetes. Int. Immunol. 13(6), 825-833 (2001)

84 Ochi H, Abraham M, Ishikawa $\mathrm{H}$ et al. New immunosuppressive approaches: Oral administration of CD3-specific antibody to treat autoimmunity. J. Neurol. Sci. 274(1-2), 9-12 (2008).

85 da Cunha AP, Weiner HL. Induction of immunological tolerance by oral anti-CD3. Clin. Dev. Immunol. 2012, 425021 (2012).

86 Andersson J, Tran DQ, Pesu M et al. CD4+FoxP3+ regulatory $\mathrm{T}$ cells confer infectious tolerance in a TGF-dependent manner. J. Exp. Med. 205(9), 1975-1981 (2008).

87 Chen M-L, Yan B-S, Bando Y, Kuchroo VK, Weiner HL. Latency-associated peptide identifies a novel CD4+CD25+ regulatory $\mathrm{T}$ cell subset with TGFbeta-mediated function and enhanced suppression of experimental autoimmune encephalomyelitis. J. Immunol. 180 (11), 7327-7337 (2008).

88 Oliveira VG, Caridade M, Paiva RS, Demengeot J, Graca L. Sub-optimal CD4 + T-cell activation triggers autonomous TGF- $\beta$-dependent conversion to Foxp $3+$ regulatory T cells. Eur. J. Immunol. 41(5), 1249-1255 (2011).

89 Wu H, Center E, Tsokos G, Weiner H. Suppression of murine SLE by oral anti-CD3: inducible CD 4+CD25-LAP+ regulatory $\mathrm{T}$ cells control the expansion of IL-17+ follicular helper T cells. Lupus 18(7), 586-596 (2009).

90 Wu HY, Quintana FJ, da Cunha AP et al. In vivo induction of $\operatorname{Tr} 1$ cells via mucosal dendritic cells and AHR signaling. PLoS ONE 6(8), e23618 (2011).

91 Cole MS, Stellrecht KE, Shi JD et al. HuM291, a humanized anti-CD3 antibody, is immunosuppressive to $T$ cells while exhibiting reduced mitogenicity in vitro. Transplantation 68(4), 563-571 (1999).

92 Dean Y, Dépis F, Kosco-Vilbois M. Combination therapies in the context of anti-CD3 antibodies for the treatment of autoimmune diseases. Swiss Med. Wkly 142, w13711 (2012).

93 Friend PJ, Hale G, Chatenoud L et al. Phase I study of an engineered aglycosylated humanized CD3 antibody in renal transplant rejection. Transplantation 68(11), 1632-1637 (1999).

94 Alegre ML, Tso JY, Sattar HA et al. An anti-murine CD3 monoclonal antibody with a low affinity for Fc gamma receptors suppresses transplantation responses while minimizing acute toxicity and immunogenicity. J. Immunol. 155(3), 1544-1555 (1995).

95 Herold KC, Hagopian W, Auger JA et al. Anti-CD3 monoclonal antibody in new-onset type 1 diabetes mellitus. N. Engl. J. Med. 346(22), 1692-1698 (2002).

-• First clinical trial testing the therapeutic effect the antiCD3 $\mathrm{mAb}$ teplizumab in patients with Type 1 diabetes and demonstrating treatment benefit in patients having received anti-CD3 $\mathrm{mAb}$.

96 Herold KC, Gitelman SE, Masharani U et al. A single course of anti-CD3 monoclonal antibody hOKT3gammal (Ala-Ala) results in improvement in C-peptide responses and clinical parameters for at least 2 years after onset of type 1 diabetes. Diabetes 54(6), 1763-1769 (2005).

97 Keymeulen B, Vandemeulebroucke E, Ziegler AG et al. Insulin needs after CD3-antibody therapy in new-onset type 1 diabetes. N. Engl. J. Med. 352(25), 2598-2608 (2005).

-. Clinical trial testing the therapeutic effect of the antiCD3 mAb otelixizumab in patients with Type 1 diabetes. Patients with the highest residual beta-cell function at the beginning of the trial had highest benefits from the antiCD3 mAb therapy.

98 Keymeulen B, Walter M, Mathieu C et al. Four-year metabolic outcome of a randomised controlled CD3antibody trial in recent-onset type 1 diabetic patients depends on their age and baseline residual beta cell mass. Diabetologia 53(4), 614-623 (2010).

99 Sherry N, Hagopian W, Ludvigsson J et al. Teplizumab for treatment of type 1 diabetes (Protégé study): 1-year results from a randomised, placebo-controlled trial. Lancet 378(9790), 487-497 (2011).

100 Aronson R, Gottlieb PA, Christiansen JS et al. Low-dose otelixizumab anti-CD3 monoclonal antibody DEFEND-1 study: results of the randomized phase III study in recent-onset human type 1 diabetes. Diabetes Care 37(10), 2746-2754 (2014).

101 Ambery P, Donner TW, Biswas N, Donaldson J, Parkin J, Dayan CM. Efficacy and safety of low-dose otelixizumab anti-CD3 monoclonal antibody in preserving C-peptide secretion in adolescent type 1 diabetes: DEFEND-2, a randomized, placebo-controlled, double-blind, multi-centre study. Diabet. Med. 31(4), 399-402 (2014).

102 Hagopian W, Ferry RJ, Sherry N et al. Teplizumab preserves $\mathrm{C}$-peptide in recent-onset type 1 diabetes: two-year results 
from the randomized, placebo-controlled Protégé trial. Diabetes 62(11), 3901-3908 (2013).

103 Herold KC, Gitelman SE, Ehlers MR et al. Teplizumab (anti-CD3 $\mathrm{mAb}$ ) treatment preserves $\mathrm{C}$-peptide responses in patients with new-onset type 1 diabetes in a randomized controlled trial: metabolic and immunologic features at baseline identify a subgroup of responders. Diabetes 62(11), 3766-3774 (2013).

104 Plevy S, Salzberg B, Van Assche G et al. A Phase I Study of Visilizumab, a Humanized Anti-CD3 Monoclonal Antibody, in Severe Steroid-Refractory Ulcerative Colitis. Gastroenterology 133(5), 1414-1422 (2007).

105 Sandborn WJ, Colombel JF, Frankel M et al. Anti-CD3 antibody visilizumab is not effective in patients with intravenous corticosteroid-refractory ulcerative colitis. Gut 59(11), 1485-1492 (2010).

106 van der Woude CJ, Stokkers P, van Bodegraven AA et al. Phase I, double-blind, randomized, placebo-controlled, dose-escalation study of NI-0401 (a fully human antiCD3 monoclonal antibody) in patients with moderate to severe active Crohn's disease. Inflamm. Bowel Dis. 16(10), 1708-1716 (2010).

107 Ilan Y, Zigmond E, Lalazar G et al. Oral administration of OKT3 monoclonal antibody to human subjects induces a dose-dependent immunologic effect in T cells and dendritic cells. J. Clin. Immunol. 30 (1), 167-177 (2009).

108 Halota W, Ferenci P, Kozielewicz D et al. Oral anti-CD3 immunotherapy for $\mathrm{HCV}$-nonresponders is safe, promotes regulatory $T$ cells and decreases viral load and liver enzyme levels: results of a phase-2a placebo-controlled trial. J. Viral Hepat. 22(8), 651-657 (2015).

109 Lalazar G, Mizrahi M, Turgeman I et al. Oral administration of OKT3 MAb to patients with NASH, promotes regulatory T-cell induction, and alleviates insulin resistance: results of a phase IIa blinded placebo-controlled trial. J. Clin. Immunol. 35(4), 399-407 (2015).

-• Shows that oral anti-CD3 $\mathrm{mAb}$ therapy is beneficial for NASH patients, improving metabolic and immunologic parameters and confirms the good safety profile that has been previously described.

110 Woodle ES, Xu D, Zivin RA et al. Phase I trial of a humanized, Fc receptor nonbinding OKT3 antibody, huOKT3gammal(Ala-Ala) in the treatment of acute renal allograft rejection. Transplantation 68(5), 608-616 (1999).

111 Keymeulen B, Candon S, Fafi-Kremer S et al. Transient Epstein-Barr virus reactivation in $\mathrm{CD} 3$ monoclonal antibody-treated patients. Blood 115(6), 1145-1155 (2010).

112 Chatenoud L, Legendre C, Ferran C, Bach J-F, Kreis H. Corticosteroid inhibition of the OKT3-induced cytokinerelated syndrome-dosage and kinetics prerequisites. Transplantation 51(2), 334-338 (1991).

113 Shield CF, Kahana L, Pirsch J et al. Use of indomethacin to minimize the adverse reactions associated with orthoclone OKT3 treatment of kidney allograft rejection. Transplantation 54(1), 164-166 (1992).

114 Alegre ML, Gastaldello K, Abramowicz D et al. Evidence that pentoxifylline reduces anti-CD3 monoclonal antibody- induced cytokine release syndrome. Transplantation 52(4), 674-679 (1991).

115 Ferran C, Dy M, Merite $S$ et al. Reduction of morbidity and cytokine release in anti-CD3 MoAb-treated mice by corticosteroids. Transplantation 50(4), 642-648 (1990).

116 Alegre ML, Vandenabeele P, Depierreux M et al. Cytokine release syndrome induced by the $145-2 \mathrm{C} 11$ anti-CD3 monoclonal antibody in mice: prevention by high doses of methylprednisolone. J. Immunol. 146(4), 1184-1191 (1991).

117 Ferran C, Dy M, Sheehan K et al. Cascade modulation by anti-tumor necrosis factor monoclonal antibody of interferon-gamma, interleukin 3 and interleukin 6 release after triggering of the $\mathrm{CD} 3 / \mathrm{T}$ cell receptor activation pathway. Eur. J. Immunol. 21(10), 2349-2353 (1991).

118 Charpentier B, Hiesse C, Lantz O et al. Evidence that antihuman tumor necrosis factor monoclonal antibody prevents OKT3-induced acute syndrome. Transplantation 54(6), 997-1002 (1992).

119 Valle A, Jofra T, Stabilini A, Atkinson M, Roncarolo M-G, Battaglia M. Rapamycin prevents and breaks the anti-CD3induced tolerance in NOD mice. Diabetes 58(4), 875-881 (2009).

120 Belmar NA, Lombardo JR, Chao DT et al. Dissociation of efficacy and cytokine release mediated by an Fc-modified anti-CD3 $\mathrm{mAb}$ in a chronic experimental autoimmune encephalomyelitis model. J. Neuroimmunol. 212(1-2), 65-73 (2009).

121 Montero N, Pascual J. Immunosuppression and posttransplant hyperglycemia. Curr. Diabetes Rev. 11(3), 144-154 (2015).

122 Zhang D, Tu E, Kasagi S, Zanvit P, Chen Q, Chen W. Manipulating regulatory $T$ cells: a promising strategy to treat autoimmunity. Immunotherapy 7(11), 1201-1211 (2015).

123 Mamchak AA, Manenkova Y, Leconet W et al. Preexisting autoantibodies predict efficacy of oral insulin to cure autoimmune diabetes in combination with anti-CD3. Diabetes 61(6), 1490-1499 (2012).

124 Takiishi T, Korf H, Van Belle TL et al. Reversal of autoimmune diabetes by restoration of antigen-specific tolerance using genetically modified Lactococcus lactis in mice. J. Clin. Invest. 122(5), 1717-1725 (2012).

125 Bresson D, Fousteri G, Manenkova Y, Croft M, Herrath von M. Journal of autoimmunity. J. Autoimmun. 37(4), 342-351 (2011).

126 Sherry NA, Chen W, Kushner JA et al. Exendin-4 improves reversal of diabetes in NOD mice treated with anti-CD3 monoclonal antibody by enhancing recovery of beta-cells. Endocrinology 148(11), 5136-5144 (2007).

127 Hering BJ, Kandaswamy R, Harmon JV et al. Transplantation of cultured islets from two-layer preserved pancreases in type 1 diabetes with anti-CD3 antibody. $\mathrm{Am}$. J. Transplant. 4(3), 390-401 (2004).

128 Bellin MD, Barton FB, Heitman A et al. Potent induction immunotherapy promotes long-term insulin independence after islet transplantation in type 1 diabetes. Am. J. Transplant. 12(6), 1576-1583 (2012). 
129 Begum S, Chen W, Herold KC, Papaioannou VE. Remission of type 1 diabetes after anti-CD3 antibody treatment and transplantation of embryonic pancreatic precursors. Endocrinology 150(10), 4512-4520 (2009).

130 You S, Piali L, Kuhn C et al. Therapeutic use of a selective S1P1 receptor modulator ponesimod in autoimmune diabetes. PLoS ONE 8(10), e77296 (2013).

131 Nepom GT, Ehlers M, Mandrup-Poulsen T. Anti-cytokine therapies in T1D: concepts and strategies. Clin. Immunol. 149(PA), 279-285 (2013).

132 Ablamunits V, Henegariu O, Hansen JB et al. Synergistic reversal of type 1 diabetes in NOD mice with anti-CD3 and interleukin-1 blockade: evidence of improved immune regulation. Diabetes 61(1), 145-154 (2012).

133 Malfait AM, Williams RO, Malik AS, Maini RN, Feldmann M. Chronic relapsing homologous collagen-induced arthritis in DBA/1 mice as a model for testing disease-modifying and remission-inducing therapies. Arthritis Rheum. 44(5), 1215-1224 (2001).

134 Dépis F, Hatterer E, Lamacchia C et al. Long-term amelioration of established collagen-induced arthritis achieved with short-term therapy combining anti-CD3 and anti-tumor necrosis factor treatments. Arthritis Rheum. 64(10), 3189-3198 (2012).

135 Baan CC, Gaston RS. Report of a joint ESOT and AST meeting: highlights in biologic agents and transplantation. Am. J. Transplant. 11(4), 681-686 (2011).

136 Presta LG. Molecular engineering and design of therapeutic antibodies. Curr. Opin. Immunol. 20(4), 460-470 (2008).

137 Chan AC, Carter PJ. Therapeutic antibodies for autoimmunity and inflammation. Nat. Rev. Immunol. 10(5), 301-316 (2010).

138 Reichert JM. Metrics for antibody therapeutics development. MAbs 2(6), 695-700 (2010). 